\title{
Production and nutrition of irrigated Tanzania guinea grass in response to nitrogen fertilization
}

\author{
Maria Celuta Machado Viana ${ }^{1}$, Inêz Pereira da Silva ${ }^{2}$, Francisco Morel Freire ${ }^{1}$, Mozart Martins \\ Ferreira $^{2}$, Édio Luiz da Costa $^{3}$, Maria Helena Tabim Mascarenhas ${ }^{1}$, Matheus Ferreira França \\ Teixeira $^{1}$
}

\author{
${ }^{1}$ EPAMIG Centro-Oeste - Prudente de Morais, MG, Brasil. \\ ${ }^{2}$ Departamento de Ciência do Solo, Universidade Federal de Lavras - Lavras, MG, Brasil. \\ ${ }^{3}$ Universidade Federal de São João Del Rei - Sete Lagoas, MG, Brasil.
}

\begin{abstract}
The objective of this study was to evaluate the effects of nitrogen $(\mathrm{N})$ fertilization in the four seasons of the year on forage production, nitrate $\left(\mathrm{NO}_{3}\right)$ in the sap, total $\mathrm{N}$ in the forage and relative chlorophyll index (SPAD reading) in the leaves of irrigated Panicum maximum cv. Tanzania grass, establishing their critical ranges. In addition, we evaluated the ability to predict forage production based on $\mathrm{NO}_{3}$ in the sap, total $\mathrm{N}$ in the forage and relative chlorophyll index. The soil in the experimental area was classified as an Oxisol (Red-Yellow Latosol) with a clayey texture. Annual rates of N (0, 200,400 and $800 \mathrm{~kg} \mathrm{ha}^{-1}$ ) in the form of urea were the treatments tested. Irrigation was performed through a conventional spray system. The $\mathrm{NO}_{3}$ content in the sap and the relative chlorophyll index were measured in leaves using a portable meter with $\mathrm{NO}_{3}$ selective electrode and the SPAD-502 portable chlorophyll meter device, respectively. Tanzania guinea grass was very responsive to $\mathrm{N}$ fertilization, except in the winter. The critical ranges of the SPAD reading proved to be more adequate for monitoring the nutritional state of $\mathrm{N}$ of Tanzania guinea grass in the different seasons of the year than the $\mathrm{NO}_{3}$ content in the sap and the total $\mathrm{N}$ content in the dry matter. Use of the chlorophyll meter is more advantageous than the use of the portable meter with an nitrate selective electrode for predicting the nutritional status of Tanzania guinea grass.
\end{abstract}

Key Words: chlorophyll, $\mathrm{NO}_{3}$ in the sap, Panicum maximum, SPAD, total $\mathrm{N}$ content

\section{Introduction}

Nitrogen deficiency has been reported as the main cause of low dry matter production or delay of biochemical functions in plant metabolism, since $\mathrm{N}$ is part of the chlorophyll pigment structure and is involved in $\mathrm{NO}_{3}$ reductase activation (Lavres Junior et al., 2010). In the search of technologies to correct management of $\mathrm{N}$ fertilization, rates of $\mathrm{N}$ have been quantified as based on results of $\mathrm{N}$ analysis in the soil and in the plant. According to Minnoti et al. (1989) and Tremblay et al. (1999), determinations of $\mathrm{N}$ in the dry matter may have questionable practical viability since, in addition to their high cost, they require a great deal of time from sample collection to obtaining results. These contents often do not reflect the nutritional state of the plant in relation to $\mathrm{N}$. To get around this problem, determinations of chlorophyll contents by a chlorophyll meter and of $\mathrm{NO}_{3}$

Received July 24, 2013 and accepted February 25, 2014.

Corresponding author: mcv@epamig.br

http://dx.doi.org/10.1590/S1516-35982014000500003

Copyright @ 2014 Sociedade Brasileira de Zootecnia. This is an Open Access article distributed under the terms of the Creative Commons Attribution Non-Commercial License, which permits unrestricted non-commercial use, distribution, and reproduction in any medium, provided the original work is properly cited. in the sap by means of a portable meter equipped with a specific microelectrode for $\mathrm{NO}_{3}$ have been recommended as auxiliary tools for monitoring the nutritional state of $\mathrm{N}$ in the plants. Because they provide quick results, these technologies allow for corrections in the $\mathrm{N}$ fertilization program to be made during the crop cycle. The potential of $\mathrm{NO}_{3}$ analysis in leaf sap has been shown in various studies with vegetable crops (Huett and White, 1992; Fontes et al., 2003). However, for forage grasses, studies are still very much in the initial stages.

The SPAD-502 portable chlorophyll meter is a useful device for indirect determination of the $\mathrm{a}+\mathrm{b}$ chlorophyll content in plant leaf tissue (Yadava, 1986). This chlorophyll meter expresses the results in SPAD unit values and has the advantages of being portable, light weight, and easily handled. It may be used in field conditions without the need for destroying the sampled part of the plant. Its use for monitoring the nutritional state of $\mathrm{N}$ has been evaluated in forage grasses with satisfactory results (Premazzi et al., 2003; Erthal et al, 2010). However, calibration for forage grasses is necessary.

The aim of this study was to evaluate the effects of $\mathrm{N}$ fertilization in the four seasons of the year with respect to forage production, $\mathrm{NO}_{3}$ content in the sap, total $\mathrm{N}$ content 
in the forage, and the relative chlorophyll index (SPAD reading) in the leaves of irrigated Panicum maximum cv. Tanzania guinea grass as well as to establish its critical ranges and evaluate its predictive ability for forage production based on these variables.

\section{Material and Methods}

The experiment was set up at Santa Rita Experimental Farm/EPAMIG, Prudente de Morais, MG, Brazil, located at $19^{\circ} 27^{\prime} 15^{\prime \prime}$ latitude south, $44^{\circ} 09^{\prime} 11^{\prime \prime}$ longitude west, at $732 \mathrm{~m}$ altitude. The climate in the region is the Aw type, with two well-defined seasons: dry (May to October) and rainy (November to April). The soil of the experimental area was classified as an Oxisol (Red-Yellow Latosol) with a clayey texture, according to the Brazilian soil classification system (EMBRAPA, 2006) and it was chemically analyzed before setting up the experiment (EMBRAPA, 1999). The following results were observed in the $0-20 \mathrm{~cm}$ layer: $\mathrm{pH}$ in $\mathrm{H}_{2} \mathrm{O}=6.3$; organic matter $=3.27 \mathrm{dag} \mathrm{kg}^{-1} ; \mathrm{P}=16 \mathrm{mg} \mathrm{dm}^{-3}$ (Mehlich-1); $\mathrm{K}=67 \mathrm{mg} \mathrm{dm}^{-3}$ (Mehlich-1); $\mathrm{Ca}^{2+}=4.27 \mathrm{cmol}_{\mathrm{c}} \mathrm{dm}^{-3}$; $\mathrm{Mg}^{2+}=1.16 \mathrm{cmol}_{\mathrm{c}} \mathrm{dm}^{-3}$; and $\mathrm{Al}^{3+}=0.05 \mathrm{cmol}_{\mathrm{c}} \mathrm{dm}^{-3}$. In the 20-40 cm layer the results were: $\mathrm{pH}$ in $\mathrm{H}_{2} \mathrm{O}=6.3$; organic matter $=3.07 \mathrm{dag} \mathrm{kg}^{-1} ; \mathrm{P}=8.6 \mathrm{mg} \mathrm{dm}{ }^{-3} ; \mathrm{K}=40 \mathrm{mg} \mathrm{dm}{ }^{-3}$; $\mathrm{Ca}^{2+}=3.77 \mathrm{cmol}_{\mathrm{c}} \mathrm{dm}^{-3} ; \mathrm{Mg}^{2+}=0.89 \mathrm{cmol}_{\mathrm{c}} \mathrm{dm}^{-3}$; and $\mathrm{Al}^{3+}=$ $0.05 \mathrm{cmol}_{\mathrm{c}} \mathrm{dm}^{-3}$.

The study was carried out from July/2010 to June/2011 in a Tanzania guinea grass (Panicum maximum) pasture established in November 2009 which was fertilized at planting with $50 \mathrm{~kg} \mathrm{ha}^{-1}$ of $\mathrm{P}_{2} \mathrm{O}_{5}$ (simple superphosphate), $30 \mathrm{~kg} \mathrm{ha}^{-1}$ of $\mathrm{K}_{2} \mathrm{O}$ (potassium chloride) and $50 \mathrm{~kg} \mathrm{ha}^{-1}$ of FTE BR12 (B $=1.8 \% ; \mathrm{Cu}=0.8 \% ; \mathrm{Mn}=2.0 \% ; \mathrm{Mo}=0.1 \%$; and $\mathrm{Zn}=9.0 \%$ ) according to Cantarutti et al. (1999). A randomized block experimental design was used with four replications. Annual rates of $\mathrm{N}\left(0,200,400\right.$ and $\left.800 \mathrm{~kg} \mathrm{ha}^{-1}\right)$ in the form of urea $(45 \%$ of $\mathrm{N})$ were the treatments tested. The $\mathrm{N}$ rates were divided into nine equal broadcast applications: the first soon after plot-leveling grazing and the others after each grazing cycle.

Grazing was carried out with a group of dry cows, but no measurement of animal performance was made. The animals were used only as grazers. The grazing cycle was established on the height of Tanzania guinea grass on a rotational grazing management. Sward height was monitored using a ruler graduated in centimeters through systematic readings in each paddock. Readings of sward height were taken from ground level considering the leaf horizon on the top of the sward as a reference. The animals were placed in the paddocks simultaneously when any treatment reached a height of $70 \mathrm{~cm}$. In turn, the animals were removed as the grass reached a height of $30 \mathrm{~cm}$. Then, all treatments were grazed nine times.

The experimental plot measured $720 \mathrm{~m}^{2}(24 \times 30 \mathrm{~m})$. A conventional spray irrigation system was used with buried PVC pipes, and the water level was calculated based on reference values for evapotranspiration, precipitation and the $\mathrm{Kc}$ for Tanzania guinea grass. Based on crop coefficients found in the literature for Tanzania guinea grass (Lourenço et al., 2001; Rodrigues et al., 2011), an adjustment was made to the region of Sete Lagoas, MG. The chlorophyll index (SPAD reading) and $\mathrm{NO}_{3}$ content were measured in ten totally open newly mature leaves before animals entered each paddock. A portable meter with a selective electrode for $\mathrm{NO}_{3}$ (C-141 Cardy Nitrate Meter - Horiba, Inc.) was used to determine the $\mathrm{NO}_{3}$ content in the sap. For sap extraction, 20 leaves were sampled using $2 \mathrm{~cm}$ long sections of the base of the midrib. These sections were macerated in a garlic press along with a piece of tape that goes with the aforementioned meter so as to maintain the sap released, for purposes of analysis, based on modified methodology from Guimarães (1998). The portable SPAD502 Chlorophyll Meter (Minolta) was used to determine the SPAD reading.

To evaluate dry matter production, before each grazing period, three areas of $3 \mathrm{~m}^{2}$ were sampled from each Tanzania guinea grass pasture plot, cutting the grass at $30 \mathrm{~cm}$ from the ground. Total $\mathrm{N}$ content in the dry matter was analyzed after the collected material was dried in a forced air-circulation oven at $60{ }^{\circ} \mathrm{C}$ for 72 hours, weighed and ground up, followed by determination of total $\mathrm{N}$ content by the micro Kjeldahl method.

Accumulated forage production in the various samplings within each season of the year (Winter: 07/5/2010, 08/25/2010; Spring: 10/04/2010, 11/16/2010, Summer: 12/27/2010, 01/24/2011, 02/15/2011; Fall: 03/25/2011, 05/04/2011) was used for statistical analyses. Samples from intermediate grazing cycle representative of each season (based on climatic conditions) were chosen for $\mathrm{NO}_{3}$ contents in the sap, SPAD readings and the total $\mathrm{N}$ contents in the forage.

The data were subjected to variance and regression analyses. Models were chosen based on the significance of the regression coefficients, using the $t$ test. To determine the critical ranges, mathematical models were used to estimate the $\mathrm{N}$ rates relative to the point of maximum forage dry matter production. This point of maximum production was obtained by carrying out the first derivative of the quadratic equation equal to zero. The equivalent to $90 \%$ of maximum production was determined. In turn, two new $\mathrm{N}$ rates were established by entering the value relating to maximum forage production in the same equation used in the calculation of 
point of maximum production. With these new $\mathrm{N}$ rates and equations that explain the response of SPAD reading, $\mathrm{NO}_{3}$ content in the sap and total $\mathrm{N}$ content in the forage to $\mathrm{N}$ rates applied, the critical ranges for these variables were calculated. Correlation analyses were performed to evaluate the predictive ability for forage production based on SPAD readings, $\mathrm{NO}_{3}$ content in the sap and total $\mathrm{N}$ contents in the dry matter. The SISVAR statistical program (Ferreira, 2011) was used and the regression and correlation coefficients were tested up to $10 \%$ of probability.

\section{Results and Discussion}

There were significant effects of treatments for all variables evaluated. The interactions between $\mathrm{N}$ rates and season were significant. Thus, statistical analyses were performed into each season. Accumulated dry matter production was affected by the rates of $\mathrm{N}$ applied in the seasons of the year (Tables 1 and 2). The greatest dry matter production occurred in the summer, while, in the winter, the lowest production was observed due to less favorable climatic conditions. In addition to providing an immediate effect on forage production, it may be inferred that $\mathrm{N}$ supply is strengthened by the greater quantity of rainfall and by higher temperatures observed throughout the summer months. Under tropical conditions, the temperature, moisture and luminosity during the winter are inadequate for good development of tropical $\mathrm{C} 4$ forage (Maranhão et al., 2010). In contrast, in the summer, these climatic variables are adequate and, depending on forage management conditions, high biomass production may be obtained. Maranhão et al. (2009) evaluated the productive

Table 1 - Accumulated dry matter production of Tanzania guinea grass in each season of the year according to $\mathrm{N}$ rates

\begin{tabular}{lcccc}
\hline \multirow{2}{*}{$\begin{array}{l}\text { Annual rates of } \mathrm{N} \\
\left(\mathrm{kg} \mathrm{ha}^{-1}\right)\end{array}$} & \multicolumn{4}{c}{ Accumulated dry matter production $\left(\mathrm{kg} \mathrm{ha}^{-1}\right)$} \\
\cline { 2 - 5 } & Summer & Fall & Winter & Spring \\
\hline 0 & 2,427 & 1,631 & 1,129 & 1,346 \\
200 & 3,654 & 3,381 & 1,934 & 2,895 \\
400 & 6,687 & 4,465 & 2,345 & 3,087 \\
800 & 6,747 & 4,857 & 2,126 & 4,386 \\
\hline
\end{tabular}

Table 2 - Equations that relate accumulated dry matter production $\left(\mathrm{kg} \mathrm{ha}^{-1}\right)$ of Tanzania guinea grass in each season of the year to $\mathrm{N}$ rates $\left(\mathrm{kg} \mathrm{ha}^{-1} \mathrm{yr}^{-1}\right)$

\begin{tabular}{lcc}
\hline Season of the year & \multicolumn{1}{c}{ Equation } & $\mathrm{R}^{2}$ \\
\hline Summer & $\hat{\mathrm{y}}=2116+13.820 * * \mathrm{x}-0.0099 * \mathrm{x}^{2}$ & 0.91 \\
Fall & $\hat{\mathrm{y}}=1637+10.178 * * \mathrm{x}-0.0077 * * \mathrm{x}^{2}$ & 0.99 \\
Winter & $\hat{\mathrm{y}}=1132+4.862 * * \mathrm{x}-0.0045 * * \mathrm{x}^{2}$ & 0.99 \\
Spring & $\hat{\mathrm{y}}=1706+3.494 * * \mathrm{x}$ & 0.91 \\
\hline$* *$ and * - Significant at 1 and $5 \%$ probability by the t test, respectively. &
\end{tabular}

characteristics of $B$. decumbens and reported that $\mathrm{N}$ fertilization increased dry matter production by $97 \%$ in the summer and $10 \%$ in the winter, without differences in the fall. According to Vitor et al. (2009) the greater forage production can be attributed mainly to the effects of $\mathrm{N}$, which promotes significant increase in the rates of enzymatic reactions in plant metabolism.

The maximum dry matter production values estimated corresponded to $\mathrm{N}$ rates of 540, 698 and $661 \mathrm{~kg} \mathrm{ha}^{-1}$ year $^{-1}$ in the winter, summer and fall, respectively. These rates are higher than the greatest rates recommended in the literature (Cantarutti et al., 1999; Freitas et al., 2005). It was not possible to estimate the point of maximum forage production in the spring since the response to $\mathrm{N}$ rates was linear. Maximum forage yields were obtained by entering these dosages in the equations: $2,445 \mathrm{~kg} \mathrm{ha}^{-1}$ in the winter, $6,939 \mathrm{~kg} \mathrm{ha}^{-1}$ in the summer and $5,000 \mathrm{~kg} \mathrm{ha}^{-1}$ in the fall. Despite the use of irrigation and $\mathrm{N}$ fertilization, the low temperature conditions associated with decreasing photoperiod in the winter promotes lower responses of forage dry matter production compared with the summer.

The values of the $\mathrm{NO}_{3}$ contents in the sap were affected by the $\mathrm{N}$ rates applied in the different seasons of the year (Tables 3 and 4). In the summer, an increase in $\mathrm{N}$ rates led to a linear increase in the $\mathrm{NO}_{3}$ contents. However, in the winter there was a quadratic increase in the $\mathrm{NO}_{3}$ content, and in fall and spring, this content decreased quadratically. Although not explained biologically, the quadratic model with negative linear coefficient for spring and fall suggested some resistance to increase $\mathrm{NO}_{3}$ content in the sap with application of lower rates. This behavior can be possibly attributed to the fact that spring and fall differ from the

Table 3 - Nitrate $\left(\mathrm{NO}_{3}\right)$ contents in the sap of Tanzania guinea grass in each season of the year according to $\mathrm{N}$ rates

\begin{tabular}{lcccc}
\hline \multirow{2}{*}{$\begin{array}{l}\text { Annual rates of } \mathrm{N} \\
\left(\mathrm{kg} \mathrm{ha}^{-1}\right)\end{array}$} & \multicolumn{4}{c}{$\mathrm{NO}_{3}$ content in the sap $\left(\mathrm{g} \mathrm{L}^{-1}\right)$} \\
\cline { 2 - 5 } & Summer & Fall & Winter & Spring \\
\hline 0 & 1.29 & 2.00 & 1.60 & 1.12 \\
200 & 1.53 & 1.00 & 2.43 & 1.30 \\
400 & 2.82 & 2.00 & 3.23 & 1.25 \\
800 & 3.62 & 4.33 & 3.60 & 3.38 \\
\hline
\end{tabular}

Table 4 - Equations of $\mathrm{NO}_{3}$ content in the sap of Tanzania guinea grass in each season of the year related to $\mathrm{N}$ rates

\begin{tabular}{lcc}
\hline Season of the year & \multicolumn{1}{c}{ Equation } & $\mathrm{R}^{2}$ \\
\hline Summer & $\hat{\mathrm{y}}=1.23+0.00311^{* *} \mathrm{x}$ & 0.93 \\
Fall & $\hat{\mathrm{y}}=1.88-0.00429^{* *} \mathrm{x}+0.000009^{* *} \mathrm{x}^{2}$ & 0.99 \\
Winter & $\hat{\mathrm{y}}=1.57+0.00546^{* *} \mathrm{x}-0.000004 * * \mathrm{x}^{2}$ & 0.99 \\
Spring & $\hat{\mathrm{y}}=1.20-0.00167^{* *} \mathrm{x}+0.000005^{* *} \mathrm{x}^{2}$ & 0.97 \\
\hline ** Significant at $1 \%$ probability by the t test.
\end{tabular}


other seasons in terms of temperature and radiation. According to Corrêa et al. (2007), $\mathrm{NO}_{3}$ is the only inorganic form of $\mathrm{N}$ that is accumulated in the plant when the supply of this element exceeds that required for growth. There are diverse factors that affect $\mathrm{NO}_{3}$ reduction and accumulation in plants, and they may be both genetic and environmental. Among the environmental factors, sunlight intensity is the most important because when it is low, there may be reduction in $\mathrm{NO}_{3}$ accumulation in the leaves (Faquim and Andrade, 2004).

Young plants have a greater $\mathrm{NO}_{3}$ concentration than mature plants. Nevertheless, mature plants may still have excessive concentrations of $\mathrm{NO}_{3}$ if the environmental, soil, and meteorological conditions are favorable to its accumulation in the plants. These observations are in agreement with Viana et al. (2008), who evaluated the $\mathrm{NO}_{3}$ in the sap, total $\mathrm{N}$ in the leaf, and green corn in the cob yield subjected to $\mathrm{N}$ rates and observed that the younger plants had higher free $\mathrm{NO}_{3}$ contents in the sap than the older plants, implying that greater uptake occurred in the initial development phases of the plant.

According to the adopted procedures, the critical ranges of the $\mathrm{NO}_{3}$ contents in the sap were 2.87 to $3.40 \mathrm{~g} \mathrm{~L}^{-1}$ in the winter, 2.57 to $4.21 \mathrm{~g} \mathrm{~L}^{-1}$ in the summer, and 1.62 to $5.49 \mathrm{~g} \mathrm{~L}^{-1}$ in the fall.

A significant effect of the $\mathrm{N}$ rates was observed on the total $\mathrm{N}$ concentration in the dry matter of Tanzania guinea grass. A quadratic response to the $\mathrm{N}$ doses was observed in the spring (Tables 5 and 6). The greatest concentration of $\mathrm{N}$ occurred at the rate of $593 \mathrm{~kg} \mathrm{ha}^{-1} \mathrm{yr}^{-1}$ in the spring. In the summer, there was a linear increase in the total $\mathrm{N}$ content in the forage as a result of the increase of the $\mathrm{N}$

Table 5 - Total $\mathrm{N}$ content in the dry matter of Tanzania guinea grass in each season of the year according to $\mathrm{N}$ rates

\begin{tabular}{lcccc}
\hline \multirow{2}{*}{$\begin{array}{l}\text { Annual rates of } \mathrm{N} \\
\left(\mathrm{kg} \mathrm{ha}^{-1}\right)\end{array}$} & \multicolumn{3}{c}{ Total $\mathrm{N}$ content in the dry matter $\left(\mathrm{g} \mathrm{kg}^{-1}\right)$} \\
\cline { 2 - 5 } & Summer & Fall & Winter & Spring \\
\hline 0 & 16.60 & 21.26 & 18.63 & 21.33 \\
200 & 19.59 & 15.81 & 23.47 & 29.04 \\
400 & 16.20 & 14.96 & 22.07 & 29.39 \\
800 & 25.04 & 28.68 & 22.99 & 30.87 \\
\hline
\end{tabular}

Table 6 - Equations that relate total $\mathrm{N}$ content in the dry matter of Tanzania guinea grass in each season of the year to $\mathrm{N}$ rates

\begin{tabular}{lcc}
\hline Season of the year & Equation & $\mathrm{R}^{2}$ \\
\hline Summer & $\hat{\mathrm{y}}=16.03+0.00095 * * \mathrm{x}$ & 0.63 \\
Fall & $\hat{\mathrm{y}}=21.30-0.0405 * * \mathrm{x}+0.000062 * * \mathrm{x}^{2}$ & 0.99 \\
Winter & $\hat{\mathrm{y}}=\overline{\mathrm{y}}=21.79$ & \\
Spring & $\hat{\mathrm{y}}=21.95+0.032 * * \mathrm{x}-0.000027 * * \mathrm{x}^{2}$ & 0.91 \\
\hline
\end{tabular}

** Significant at $1 \%$ probability by the $\mathrm{t}$ test. rates applied. In the fall, there was a quadratic reduction in the total $\mathrm{N}$ contents, a biologically unexplained behavior. These results can be explained by dilution effect due to a greater increase in forage production on intermediate $\mathrm{N}$ rates (Table 1). There was no response to the $\mathrm{N}$ applied in the winter. Temperature and sunlight affect plant growth and ability to extract the soil nutrient. According to Prado (2008), N deficiency restricts tillering of forage plants and, more importantly, limits the growth of individual leaves and their photosynthetic ability. For Marandu grass, Primavesi et al. (2006) observed that as the $\mathrm{N}$ rates in the form of urea and ammonium nitrate increased the $\mathrm{N}$ content in the plant in a linear and quadratic response, respectively.

The critical ranges of total $\mathrm{N}$ in the dry matter were 16.44 to $16.95 \mathrm{~g} \mathrm{~kg}^{-1}$ in the summer and 15.08 to $36.20 \mathrm{~g} \mathrm{~kg}^{-1}$ in the fall. Due to a bad adjustment of the regression equation for fall (Table 6), the critical range calculated for this season did not show a biological explanation.

An effect of the $\mathrm{N}$ rates on the SPAD reading was seen in all seasons, with quadratic responses (Tables 7 and 8). Similar results of the SPAD reading were observed by Costa et al. (2009) for Brachiaria brizantha cultivars. These authors found that the increase in $\mathrm{N}$ doses led to a quadratic increase in biomass production. In the present study, the lowest values of the SPAD reading were observed in the winter period. In this season, the greatest SPAD reading was obtained with the annual rate of $747 \mathrm{~kg} \mathrm{ha}^{-1} \mathrm{~N}$, whereas in the summer, the estimated annual rate was $633 \mathrm{~kg} \mathrm{ha}^{-1} \mathrm{~N}$. This behavior may be attributed to the lower metabolic activity of the grass in the winter, reflecting more restrictive temperature and sunlight conditions in this period.

Table 7 - Relative chlorophyll index (SPAD reading) of Tanzania guinea grass in each season of the year according to $\mathrm{N}$ rates

\begin{tabular}{lcccc}
\hline \multirow{2}{*}{$\begin{array}{l}\text { Annual rates of } \mathrm{N} \\
\left(\mathrm{kg} \mathrm{ha}^{-1}\right)\end{array}$} & \multicolumn{4}{c}{ SPAD reading } \\
\cline { 2 - 5 } & Summer & Fall & Winter & Spring \\
\hline 0 & 35.53 & 38.29 & 33.85 & 38.36 \\
200 & 41.11 & 41.30 & 38.42 & 40.38 \\
400 & 43.97 & 45.99 & 40.85 & 45.14 \\
800 & 47.85 & 48.95 & 43.24 & 44.49 \\
\hline
\end{tabular}

Table 8 - Equations relating the relative chlorophyll index (SPAD reading) in each season of the year to $\mathrm{N}$ rates

\begin{tabular}{lrc}
\hline Season of the year & \multicolumn{1}{c}{ Equation } & $\mathrm{R}^{2}$ \\
\hline Summer & $\hat{\mathrm{y}}=35.70+0.0279 * * \mathrm{x}-0.000016 * * \mathrm{x}^{2}$ & 0.99 \\
Fall & $\hat{\mathrm{y}}=37.98+0.0231 * * \mathrm{x}-0.000012 * * \mathrm{x}^{2}$ & 0.98 \\
Winter & $\hat{\mathrm{y}}=33.96+0.0239 * * \mathrm{x}-0.000016 * * \mathrm{x}^{2}$ & 0.99 \\
Spring & $\hat{\mathrm{y}}=37.86+0.0228 * * \mathrm{x}-0.000018 * * \mathrm{x}^{2}$ & 0.90 \\
\hline$* *$ Significant at $1 \%$ probability by the t test.
\end{tabular}


Table 9 - Correlation between dry matter production and SPAD reading, $\mathrm{NO}_{3}$ content in the sap and total $\mathrm{N}$ in the dry matter in each season of the year

\begin{tabular}{lllll}
\hline \multirow{2}{*}{ Characteristics } & \multicolumn{4}{c}{ Linear correlation coefficients (r) } \\
\cline { 2 - 5 } & Summer & Fall & Winter & Spring \\
\hline \multirow{4}{*}{ Dry matter production } \\
SPAD reading & $0.927^{\circ}$ & $0.959^{*}$ & $0.900^{\circ}$ & $0.816 \mathrm{~ns}$ \\
NO3 in the sap & $0.949^{*}$ & $0.518 \mathrm{~ns}$ & $0.904^{\circ}$ & $0.818 \mathrm{~ns}$ \\
Total N & $0.426 \mathrm{~ns}$ & $0.183 \mathrm{~ns}$ & $0.831 \mathrm{~ns}$ & $0.930^{\circ}$ \\
\hline
\end{tabular}

$*$ and ${ }^{\circ}$ - Significant at 5 and $10 \%$ probability by the $\mathrm{t}$ test, respectively; ns - not significant.

In regard to the critical ranges of the SPAD reading determined for the seasons, the following values were found: 47.48 to 61.07 SPAD units in the summer, 45.38 to 49.07 SPAD units in the fall and 39.79 to 42.87 SPAD units in the winter. These critical ranges of SPAD reading compared with those reported for the $\mathrm{NO}_{3}$ content in the sap and total $\mathrm{N}$ content in the dry matter, considering their amplitudes and ease of determination in practical terms, proved to be more adequate for monitoring the nutritional state of Tanzania guinea grass in regard to $\mathrm{N}$ in the seasons of the year.

For prediction of forage production, the relative chlorophyll index (SPAD reading) proved to be more efficient than the $\mathrm{NO}_{3}$ content in the sap (Table 9). In the four seasons of the year, correlation coefficients $(n=16)$ of $0.77^{* *}$ (significant at $1 \%$ by the $\mathrm{t}$ test), $0.47^{\circ}$ (significant at $10 \%$ probability by the $t$ test), and 0.060 (non-significant) were obtained for the variables of SPAD reading, $\mathrm{NO}_{3}$ content in the sap, and total $\mathrm{N}$ in the dry matter, respectively. The SPAD reading had good predictive ability for forage production in the winter, fall and summer, while the $\mathrm{NO}_{3}$ content in the sap proved to be appropriate only in the winter and summer. The lower predictive ability of the $\mathrm{NO}_{3}$ content in the sap may be attributed to a higher variability of the results. In part, this can be explained by the difficulty of sap extracting from the midrib of the leaf, which impaired the determination of its content by the portable meter with the $\mathrm{NO}_{3}$ selective electrode. Operational aspects may often create difficulties for use of analytical methods.

In terms of comparison, both the chlorophyll meter and the portable meter with $\mathrm{NO}_{3}$ selective electrode may be used as tools for monitoring the nutritional state of Tanzania guinea grass in regard to $\mathrm{N}$ content. In regard to the practicality of their use, the chlorophyll meter, in addition to having greater predictive ability for forage production, may be more advantageous due to its easy handling and possibility for use in field conditions without the need for destruction of the sampled part of the plant.

\section{Conclusions}

Tanzania guinea grass is very responsive to nitrogen fertilization, reflecting the climatic conditions more favorable to its development in summer, fall and spring. The critical ranges of SPAD reading are more adequate for monitoring the nutritional state of Tanzania guinea grass than the nitrate content in the sap and the total nitrogen content in the dry matter of the forage. Nitrate content in the sap of Tanzania guinea grass, and the SPAD reading demonstrate good ability for predicting dry matter production, constituting good indicators of the nutrition of this plant. Therefore, the use of the chlorophyll meter proves to be more advantageous than the use of the portable meter with nitrate selective electrode.

\section{Acknowledgments}

To Fundação de Amparo à Pesquisa do Estado de Minas Gerais (FAPEMIG) for financial support and granting the BIPDT fellowship.

\section{References}

Cantarutti, R. B.; Martins, C. E.; Carvalho, M. M.; Carvalho, M. M.; Fonseca, D. M.; Arruda, M. L.; Vilela, H. and Oliveira, F. T. T. 1999. Pastagens. p.332-341. In: Recomendações para o uso de corretivos e fertilizantes em Minas Gerais: $5^{\mathrm{a}}$ aproximação. Ribeiro, A. C.; Guimarães, P. T. G. and Alvarez V., V. H., eds. CFSEMG, Viçosa, MG.

Corrêa, L. A.; Cantarella, H.; Primavesi, A. C.; Primavesi, O.; Freitas, A. R. and Silva, A. G. 2007. Efeito de fontes e doses de nitrogênio na produção e qualidade da forragem de capim-coastcross. Revista Brasileira de Zootecnia 36:763-772.

Costa, K. A. P.; Oliveira, I. P.; Faquin, V.; Silva, G. P. and Severiano, E. C. 2009. Produção de massa seca e nutrição nitrogenada de cultivares de Brachiaria brizantha (A. Rich) Stapf sob doses de nitrogênio. Ciência e Agrotecnologia 33:1578-1585.

EMBRAPA - Empresa Brasileira de Pesquisa Agropecuária. Embrapa Solos, Embrapa Informática Agropecuária. 1999. Manual de análises químicas de solos, plantas e fertilizantes. Embrapa Comunicação para Transferência de Tecnologia, Brasília.

EMBRAPA - Empresa Brasileira de Pesquisa Agropecuária. Centro Nacional de Pesquisa de Solos. 2006. Sistema brasileiro de classificação de solos. 2.ed. Embrapa Solos, Rio de Janeiro.

Erthal, V. J. T.; Ferreira, P. A.; Pereira, O. G. and Matos, A. T. 2010. Características fisiológicas, nutricionais e rendimento de forrageiras fertigadas com água residuária de bovinocultura. Revista Brasileira de Engenharia Agrícola e Ambiental 14:458-466.

Faquin, V. and Andrade, A. T. 2004. Nutrição mineral e diagnose do estado nutricional de hortaliças. Universidade Federal de Lavras, FAEPE, Lavras.

Fontes, P. C. R.; Coelho, E. L. and Cardoso, A. A. 2003. Petiole sap nitrate and leaf nitrogen critical values in melon plants grown in unheated greenhouse and field conditions. Journal of Plant Nutrition 26:1403-1411.

Ferreira, D. F. 2011. Sisvar: A computer statistical analysis system. Ciência e Agrotecnologia 35:1039-1042. 
Freitas, K. R.; Rosa, B.; Ruggiero, J. A.; Nascimento, J. L.; Heinemam, A. B.; Ferreira, P. H. and Macedo, R. 2005. Avaliação do capim Mombaça (Panicum maximum Jacq.) submetido a diferentes doses de nitrogênio. Acta Scientiarum Agronomy 27:83-89.

Guimarães, T. G. 1998. Nitrogênio no solo e na planta, teor de clorofila e produção do tomateiro, no campo e na estufa, influenciados por doses de nitrogênio. Tese (D.Sc.). Universidade Federal de Viçosa, Viçosa, MG, Brasil.

Huett, D. O. and White, E. 1992. Determination of critical nitrogen concentration of lettuce (Lactuca sativa L. cv. Montello) grown in sand culture. Australian Journal of Experimental Agriculture 32:759-764.

Lavres Junior, J.; Santos Junior, J. D. G. and Monteiro, F. A. 2010. Nitrate reductase activity and spad readings in leaf tissues of guinea grass submitted to nitrogen and potassium rates. Revista Brasileira de Ciência do Solo 34:801-809.

Lourenço, L. F.; Coelho, D. D.; Soria, L. G. T.; Pinheiro, V. D. and Corsi, M. 2001. Coeficiente de cultura (Kc) do capim tanzânia (Panicum maximum Jack.) irrigado por pivô central. In: Anais da $38^{\mathrm{a}}$ Reunião Anual da Sociedade Brasileira de Zootecnia, Piracicaba. Sociedade Brasileira de Zootecnia, Brasília; FEALQ, Piracicaba.

Maranhão, C. M. A.; Bonomo, P.; Pires, A. J. V.; Costa, A. C. P. R.; Martins, G. C. F. and Cardoso, E. O. 2010. Características produtivas do capim-braquiária submetido a intervalos de corte e adubação nitrogenada durante três estações. Acta Scientiarum. Animal Sciences 32:375-384.

Maranhão, C. M. A.; Silva, C. C. F.; Bonomo, P. and Pires, A. J. V. 2009. Produção e composição químico bromatológica de duas cultivares de braquiária adubadas com nitrogênio e sua relação com o índice SPAD. Acta Scientiarum. Animal Sciences 31:117-122.
Minnoti, P. L.; Hankinson, T. J.; Grubingere, V. P. and Wien, H. C. 1989. Whole leaves versus petioles for assessing the nitrogen "status" of tomatoes. HortScience 24:84-86.

Prado, R. M. 2008. Manual de nutrição de plantas forrageiras. 1.ed. FUNEP, Jaboticabal.

Premazzi, L.; Monteiro, F. A. and Corrente, J. E. 2003. Tillering of tifton 85 bermudagrass in response to nitrogen rates and time of application after cutting. Scientia Agrícola 60:565-571.

Primavesi, A. C.; Primavesi, O.; Corrêa, L. A.; Silva, A. G. and Cantarella, H. 2006. Nutrientes na fitomassa de capim-marandu em função de fontes e doses de nitrogênio. Ciência e Agrotecnologia 30:562-568.

Rodrigues, B. H. N; Andrade, A. C.; Magalhães, J. A.; Bastos, E. A. and Santos, F. J. S. 2011. Evapotranspiração e coeficiente de cultura do capim-tanzânia. Boletim de Pesquisa e Desenvolvimento/Embrapa Meio-Norte, 98. Embrapa Meio-Norte, Teresina.

Tremblay, N.; Scharf, H. C.; Weier, U.; Laurence, H. and Owen, J. 1999. Nitrogen management in field vegetables. A guide to efficient fertilization. Agriculture and Agri-Food Canada.

Viana, M. C. M.; Freire, F. M.; Mascarenhas, M. T. M.; Gonçalves, L. D.; Coelho, A. M.; Andrade, C. L. T. and Lara, J. F. R. 2008. Teores de nitrato na seiva e de nitrogênio total na folha e produção de milho-verde submetidos a doses de nitrogênio. In: Anais do 27ำ Congresso Nacional de Milho e Sorgo. IAPAR/Embrapa Milho e Sorgo, Londrina.

Vitor, C. M. T.; Fonseca, D. M.; Cosér, A. C.; Martins, C. E.; Nascimento Júnior, D. and Ribeiro Júnior, J. I. 2009. Produção de matéria seca e valor nutritivo de pastagem de capim-elefante sob irrigação e adubação nitrogenada. Revista Brasileira de Zootecnia $38: 435-442$.

Yadava, N. L. 1986. A rapid and non destructive method to determine chlorophyll in intact leaves. HortScience 21:1149-1450. 